\title{
Transitional justice in Brazil: from military rule to a new constitutional order ${ }^{*}$
}

\author{
Mario Drumond Coelho'
}

\section{Abstract}

The implementation of transitional justice in Latin American countries that experienced military rule is still a challenge to many nations of the region. Due to different political, cultural and historical reasons, distinct transitional justice models have been utilized in Latin America. The current article intends to analyze some issues and problems related to the transitional justice experience of Brazil, a country controlled by military forces from 1964 to 1985 . The article includes a brief history of Brazil's political singularities within the last thirty years and emphasizes the study of the notion of transitional justice in perspective of three elements: accountability, justice and reconciliation. One of the main arguments of the article rests upon the idea that the implementation of predetermined patterns of transitional justice schemes is impossible, exactly because accountability, justice and reconciliation possess and maintain diverse meanings in different countries with dissimilar political, cultural and historical backgrounds. The process upon how these elements bond to rationally accomplish transitional justice unquestionably represents an issue to be considered by governments and civil societies in new democracies such as Brazil. Finally, the article endorses the following proposition: a functional notion of transitional justice (including different approaches concerning accountability, justice, and reconciliation) must take into consideration particular local realities and domestic contingencies of political, juridical, and cultural nature.

Key words: Transitional justice. Accountability. Justice. Reconciliation. Military regimes. New democracies in Latin America. Human rights.

\footnotetext{
* Recebido em: 03/03/11

Aprovado em: 14/06/2011

1 Professor de Direito e Relações Internacionais do Centro Universitário de Brasília. E-mail: mariodrumond@gmail.com.
} 


\section{Introduction}

From 1964 to 1985 Brazil was ruled by the military. This two-decade period, in symbolic terms, was at last surpassed in 1988, with the publication of a new Constitution. Brazil's existing constitutional text may be understood as the result of a legal and political transition from military regime to democracy. As a "response" to military rule, the Constitution of Brazil has dedicated considerable part of its text to the issue regarding the protection of human rights. The influence of the military in Brazilian politics, however, did not diminish instantaneously with the new constitutional order; as correctly pointed by Castro Santos,

The National Constituent Assembly (ACN), called by Sarney to craft a new democratic constitution, did not do much to revise the defense structure or to enhance civilian control over the military. Most decisions concerning military affairs came favorable to the interests of the corporation, although in some important issues the military were not completely happy (SANTOS, 2004, p. 119).

In addition, it must be highlighted that more than twenty years after the edition of the 1988 Constitution, the military still hold political power in Brazil (including the national and regional spheres), but in levels visibly lower than those experimented in the 60's and 70's. In a moment of political transition, the new players empowered must acquire and show their symbols as a means to consolidate the rationale of rupture. As accurately underlined by Byrnes and Renshaw, "as political documents often drafted in the wake of oppression, revolution, and the arrival of new political orders, national constitutions frequently embody the desire of their drafters to distinguish the new order from the old" (BYRNES; RENSHAW, 2010, p. 506). An innovative Constitution was thus drafted, approved, and presented to the people of Brazil in 1988. The approach on the way to human rights imagined and constructed by the drafters of the new Constitution of Brazil remains unambiguous already in the initial fragments of the text. According to Article 1,

Article 1. The Federative Republic of Brazil, formed by the indissoluble union of the states and municipalities and of the Federal District, is a legal democratic state and is founded on:

I - sovereignty;

II - citizenship;

III - the dignity of the human person; 
IV - the social values of labour and of the free enterprise; $\mathrm{V}$ - political pluralism.

Sole paragraph. All power emanates from the people, who exercise it by means of elected representatives or directly, as provided by this Constitution. ${ }^{2}$

The first article of the Brazilian Constitution lists five principles that establish the foundations of the Republic of Brazil, remaining clear the unequivocal connection between Clause III ("the dignity of the human person") and Article 1 of the Universal Declaration of Human Rights - UDHR ("All human beings are born free and equal in dignity and rights. They are endowed with reason and conscience and should act towards one another in a spirit of brotherhood"3). As a matter of fact, a wide assortment of fundamental rights established within the realm of another important article of the Brazilian Constitution (Article 5) reproduces many of those rights defined as such by the text of the UDHR.

For the purpose of one single example, Article 5 (III) of the Constitution of Brazil ascertains that "ninguém será submetido a tortura nem a tratamento desumano ou degradante" ("no one shall be submitted to torture or to inhuman or degrading treatment"4), a genuine linguistic replication of Article 5 of the UDHR: "No one shall be subjected to torture or to cruel, inhuman or degrading treatment or punishment"5 ("verbally inspired by the prohibition of "cruel and unusual punishments' in the English and American Bills of Rights, the direct stimulus for this provision was Nazi Germany's use of torture”) (RODLEY, 2010, p. 210).

Perhaps it would have been simpler if the drafters of the Constitution of Brazil had decided to automatically incorporate all the rights established within the UDHR to the approved text of 1988; nonetheless, the technique adopted was different and Article 5 of the Brazilian Constitution is certainly not a mechanical

2 Constitution of Brazil, 1988. Source: <http://www.v-brazil.com/government/laws/constitution.html>

3 The Universal Declaration of Human Rights. Source: <http://www.un.org/en/documents/ udhr/index.shtml>.

4 Constitution of Brazil, 1988. Source: <http://www.v-brazil.com/government/laws/constitution.html>.

5 The Universal Declaration of Human Rights. Source: <http://www.un.org/en/documents/ udhr/index.shtml >. 
reproduction of the aforesaid Declaration. Article 5 deals with an ample spectrum of rights, including issues directly and indirectly related to the protection of human rights.

Article 5 is indeed a kaleidoscope of rights: under the designation "Individual and Collective Rights and Duties", the aforesaid article is above all an extensive collection of rights deeply characterized by the rationale of human rights protection (including material and procedural warranties); for illustrative purposes, the first ten clauses of Article 5 contain the following directives and commands:

I - men and women have equal rights and duties under the terms of this Constitution;

II - no one shall be obliged to do or refrain from doing something except by virtue of law;

III - no one shall be submitted to torture or to inhuman or degrading treatment;

IV - the expression of thought is free, anonymity being forbidden;

$\mathrm{V}$ - the right of reply is ensured, in proportion to the offense, as well as compensation for property or moral damages or for damages to the image;

VI - freedom of conscience and of belief is inviolable, the free exercise of religious cults being ensured and, under the terms of the law, the protection of places of worship and their rites being guaranteed;

VII - under the terms of the law, the rendering of religious assistance in civil and military establishments of collective confinement is ensured;

VIII - no one shall be deprived of any rights by reason of religious belief or philosophical or political conviction, unless he invokes it to exempt himself from a legal obligation required of all and refuses to perform an alternative obligation established by law;

IX - the expression of intellectual, artistic, scientific, and communications activities is free, independently of censorship or license;

$\mathrm{X}$ - the privacy, private life, honour and image of persons are inviolable, and the right to compensation for property or moral damages resulting from their violation is ensured; ${ }^{6}$.

${ }^{6}$ Constitution of Brazil, 1988. Source: <http://www.v-brazil.com/government/laws/constitution.html>. 
It is meaningful that the issue on the subject of torture is deliberately placed as the third clause of the article, just after Clause I (affirmation of the principle of equality, certainly an introductory principle of political character) and after Clause II (assertion of the rule of law, or principle of legality, an introductory principle of legal nature). It is also very significant in political and legal terms that Clause III does not declare a right: the clause, instead, establishes a prohibition. Within the context of Brazil's dictatorial period from 1964 to 1985, it must be underlined that the institutionalized and widespread practice of torture represented a foremost operational piece of the repressive apparatus of the Brazilian military regime, especially during the phase from the end of the 60's until the first half of the 70's (precisely "the most brutal years of military rule") (KRITZ, 1995, p. 431).

Such practice, unfortunately, has resisted the path of time: almost three decades after the end of the military regime, torture remains a common practice in Brazil (independently of the region), particularly when understood as a means to an end (confessions and punishments). On the one hand, Brazilian security forces utilize torture on a regular basis in order to get hold of confessions; on the other hand, inside carceral grounds, torture is employed as a permanent tool to impose punishments over the imprisoned.

In relation to the military period, torture was fundamentally associated to those practices aiming confessions. This is particularly important to understand the rationale of the Brazilian military in relation to the nonconformists. During the military period, a dichotomy was established within the context of the regime: the generals versus the dissidents. However, all dichotomies, by definition, are inclined to ignore the "neutral zones" of a particular reality; in this case, the disinterested portions of society (mainly the Brazilian lower and middle classes, urban and rural, traditionally divorced from political participation).

In addition, the passive behaviour of the majority of the Brazilian population upon the abuses of the military rule largely contributed to legitimatize the regime itself, including its longevity: "Brazil was the first Latin American democracy to suffer a military coup in the decade of 60 and the last to get rid from the jacket of authoritarianism" (SKIDMORE, 1988, p. 595). The fact is that the passive beha- 
viour of Brazil's citizens towards political affairs remains a rooted characteristic of the nation. Such feature is certainly a factor to explain the long-established practices of corruption that undermines the credibility of the country's institutions, including the legislative, executive, and judicial branches.

Furthermore, with silence imposed upon civil society, torture became widespread within the apparatus of the regime. During the military years, civil society in Brazil (here understood in terms of institutions, such as media, labour unions, and students' organizations) was reduced to absolutely nothing. One of the few institutions performing resistance and demonstrating force against the status quo was the Catholic Church. In fact, many dissenters were directly connected to the Catholic Church during the military period.

Regarding the period following the military rule, torture in Brazil represents the typical example of a practice organically associated to a particular political establishment (military) that has forced its vigorous roots upon a subsequent political regime (democratic). It seems like a disease inside the country. Around all areas of the territory, including major cities like São Paulo, Rio de Janeiro, Belo Horizonte, Recife, and Porto Alegre, the practice of torture continues to deeply mark the reasoning and rationale of those individuals responsible for managing public security forces in the country.

Even though the Brazilian Constitution has explicitly prohibited torture, reality demonstrates that such forbidden act has not been banished from daily practices in the interior of police forces and penitentiary facilities. In a country with countless institutional ups and downs since the rise of the Republic in 1889 (including two dictatorial periods within the $20^{\text {th }}$ century), torture is still understood by a significant number of individuals as a tolerable state conduct (COIMBRA, 2001, p. 6).

\section{Transitional justice in Brazil: brief history.}

The legal and political transition mentioned in the Introduction must be understood as a movement that in fact started to occur in the final years of the 
military rule under the term of Ernesto Geisel; nevertheless, this movement gained singular momentum in 1985 with the appointment (by an electoral college within the national parliament) of Tancredo Neves as the first civilian president of Brazil after two decades of military command:

A veteran of national politics, whose career had lasted for more than 50 years, Neves seemed to be acceptable for the powerful military fearing the election of a radical. The electoral college selected Neves for president and José Sarney Costa for vice president on 19 Jan 1985. Before his inauguration, Neves underwent surgery and was unable to take office. Sarney temporarily assumed the presidency, and Neves died from complications following his surgery on 21 Apr $1985 .^{7}$

Neves died before occupying office, event that generated much speculation in 1985 due to the fact that the appointed vice-president (José Sarney) was considered a traitor inside many sectors of the military establishment. Sarney, during the years of military rule, supported the canons and edicts imposed by the generals. As a result, there was a great deal of uncertainty regarding the real possibility of Sarney taking power in Neves' place. The fact is that José Sarney (also a civilian) was placed in office as president in 1985 for a term that lasted five years.

In terms of domestic economy, Sarney's administration was an absolute catastrophe: 1,973\% annual inflation rate in 1989 combined with the milestone 82\% monthly inflation rate in March $1990^{8}$ (exactly the last month of his term). In political terms, his government was characterized and well-known for the widespread and continuous corruption inside all sectors of the federal government. ${ }^{9}$ In a period of transition, such practices severely rooted the culture of political corrup-

7 Source: <http://www.archontology.org/nations/braz/braz_rep3/neves.php >.

8 Source: <http://veja.abril.com.br/especiais/veja_40anos/p_170.html>.

9 David Fleischer accurately recovers that period: "In late 1988, a special congressional investigating committee (CPI) investigated political corruption of Sarney's government, and voted out a report recommending that impeachment proceedings be initiated. However, in early 1989, the then acting President of the Chamber of Deputies, Inocêncio de Oliveira (PFL-PE) unilaterally decided to archive the case, and not transmit same to the floor of the Chamber for a collective political decision" (source: <http://lasa.international. pitt.edu/LASA97/fleischer.pdf $>$ ). 
tion in Brazil, and José Sarney, at present one of the members of the Brazilian Senate, maintains (together with two sons and one daughter ${ }^{10}$ ) total political control of Maranhão, an extremely undeveloped state located on the northern territory of the country.

It is significant to observe that transitional justice in Brazil, in symbolic perspective, was initiated precisely at the moment that Neves was indicated President in 1985 , in the sense that the old politician ${ }^{11}$ from the traditional and conservative province of Minas Gerais embraced hopes, incarnated expectations, and personified reconciliation. It is virtually impossible to define an exact moment that would embody the beginning of transitional justice within a particular historical frame of time, but the year of 1985, with the appointment of Neves as the nation's future leader, did indeed represent such a moment.

Tancredo Neves was neither a radical from the left nor a fundamentalist from the right: regardless the meaning of center as an intermediary position inside the political spectrum, Neves was undoubtedly part of this central sphere of Brazilian politics, reason why he was not seen as an enemy to the generals (at least to most of them). As appropriately affirmed by Power, Neves "was a talented practitioner of the oldest and most important game of Brazilian politics: "conciliação das elites" (elite conciliation)" (POWER, 1987, p. 8). The idea of conciliation among elites is another indicator of how insignificant has been the political participation of the majority in Brazil (except, of course, for the formal participation of voters every two years in context of the country's electoral calendar).

It is precisely the image of conciliator that indicates the colossal responsibility placed upon Neves as the leading architect of the transition towards democracy in Brazil. Even though he did not live to face the challenge, the "embryo" of transitional justice in Brazil may be understood as a result (or perhaps a reflection) of Neves' approach to and understanding of Brazilian politics: the politics of mode-

\footnotetext{
${ }^{10}$ Zequinha Sarney, one of the sons, occupies a seat in national parliament. The daughter, Roseana Sarney, is currently the governor of the state of Maranhão.

${ }^{11} 75$ years of age in 1985 .
} 
ration (as a variant of temperance and peacemaking). In other words, the political rationale that avoids disagreement, including confrontation with the military actors that were in process of withdrawal.

Accordingly (and taking into account reconciliation as one of the fundamental elements of the notion of transitional justice), it is prudent to assert that the notion of justice in transition is at the same time broad and unsettled. Broad, on the one hand, in the sense that it embraces at least three specific (and bonding) elements: (i) accountability; (ii) justice; and (iii) reconciliation; unsettled, on the other hand, due to the fact that it is impracticable to accurately establish and uphold a crystal-clear concept of a phenomenon holding dissimilar meanings (to different people in different countries).

Taking into consideration the existence of these differences, Teitel asserts that "while repression under dictatorship in Latin America and elsewhere denoted disappearances and uncertainty, under Communist rule, repression took another, more material form, in the totality of state control over the construction of historical events. This legacy affects the historical response in transition" (TEITEL, 1999, p. 93). Analogous thought is shared by Méndez when scrutinizing transitional justice from a historical viewpoint:

Since the 1970s, there has been a virtual tidal wave of new democracies emerging from countries with an authoritarian or totalitarian past. Beginning in Southern Europe (Greece, Spain), moving through Latin America (Argentina, Chile, Brazil, Uruguay) and to Eastern Europe (Poland, East Germany, Hungary) and now in South Africa, new democratic leaderships have looked hopefully to the future. In defining a vision of this future for their populations, however, they have had to reckon with the legacy of human rights violations left by the recent authoritarian past. They all share in common this feature, even if each country chooses to adopt different measures to deal with the past. (MÉNDEZ, 1997, p. 1-2).

For the purposes of this essay, particularly on the three abovementioned elements, I have selected the notion of transitional justice established within the UN Report of the Secretary-General no S/2004/616: 
The notion of transitional justice discussed in the present report comprises the full range of processes and mechanisms associated with a society's attempts to come to terms with a legacy of large-scale past abuses, in order to ensure accountability, serve justice and achieve reconciliation. These may include both judicial and nonjudicial mechanisms, with differing levels of international involvement (or none at all) and individual prosecutions, reparations, truth-seeking, institutional reform, vetting and dismissals, or a combination thereof. ${ }^{12}$

The idea of "processes and mechanisms" is crucial to comprehend the ample connotation of transitional justice. In methodological terms, "processes and mechanisms" indicate that transitional justice is not an end in itself, but a movement towards the achievement of intangible values such as accountability, justice, and reconciliation. In other words, a means to an end, an instrument of action aiming the establishment of peace. At the same time, and still taking into account the thought regarding "processes and mechanisms", the achievement of the aforesaid values is absolutely necessary to sustain the effective implementation of public policies regarding the protection of human rights in countries that have faced the transition from military rule to democracy. In other words, how do values such as accountability, justice, and reconciliation relate as well to the protection of human rights (particularly in countries facing the issue of transitional justice)?

\subsection{The first element: accountability}

According to the definition formulated by the Economic and Social Commission for Asia and the Pacific (UNESCAP),

Accountability is a key requirement of good governance. Not only governmental institutions but also the private sector and civil society organizations must be accountable to the public and to their institutional stakeholders. Who is accountable to whom varies depending on whether decisions or actions taken are internal or external to an

\footnotetext{
12 "The rule of law and transitional justice in conflict and post-conflict societies", United Nations Security Council, S/2004/616, 23 August 2004, p. 4 (source: < http://daccess-dds-ny. un.org/doc/UNDOC/GEN/N04/395/29/PDF/N0439529.pdf?OpenElement >).
} 
organization or institution. In general an organization or an institution is accountable to those who will be affected by its decisions or actions. Accountability cannot be enforced without transparency and the rule of law. ${ }^{13}$

The definition proposed by UNESCAP seems to be tautological, but its virtue rests on the fact that accountability is contextualized in terms of good governance. But what does accountability mean exactly? Are we facing a typical case of value difficult to be defined? Perhaps there is no exact answer to the first question; regarding the second, the answer is yes. There is undoubtedly a type of accountability, for instance, characteristic of the public sector, such as accountability on the subject of budget expenditures regarding the implementation of programmes from the executive branch. Inside the private sector, accountability possesses a different dimension, such as accountability in connection to merchandising of consumer goods or accountability established within banks in relation to individual and collective investments.

Nevertheless, in perspective of transitional justice, accountability acquires a very specific connotation: issues from the past in context of the present (the rationale of "looking behind"). As precisely asserted by Méndez, "the nature of the transition to democracy itself means that there is unfinished business with respect to how we put distance between the challenges of the present and the traumas of the recent past" (MÉNDEZ, 1997, p. 3). The expression "unfinished business" accurately corroborates the conception of "a society's attempts to come to terms with a legacy of large-scale past abuses" (UN Report of the Secretary-General $\mathrm{n}^{-}$ S/2004/616).

Values and principles characterized by the element of transition are difficult to be implemented due to a decisive reason: these are values that require a balanced connection between different moments of the historical spectrum (regardless of the gap linking moment one and moment two). If we take, for example, the principle of sustainability as an indication of a transitional value, the difficulty would un-

\footnotetext{
${ }^{13}$ Source:<http://www.unescap.org/pdd/prs/ProjectActivities/Ongoing/gg/governance. asp>.
} 
questionably be the same (in this case, the connection between present and future generations in perspective of environmental protection: intergenerational equity) (SANDS, 2003, p. 235). Issues concerning past and present, or present and future, are marked precisely by the complexity (and perhaps impossibility) in establishing a substantial link between disjointed periods of time. In philosophical terms, as acknowledged by Rawls, "the life of a people is conceived as a scheme of cooperation spread out in historical time. It is to be governed by the same conception of justice that regulates the cooperation of contemporaries" (RAWLS, 2003, p. 257).

As a result, and differently from accountability in perspective of transitional justice (equation past plus present), accountability within the viewpoint of human rights protection is fundamentally a question regarding the equation present plus present (in the sense of effective implementation of public policies within present-day generations). This certainly does not mean that the protection of human rights will not impact future generations (it does indeed, in dramatic ways), but the primary scope in this case is conceptually and materially different in relation to accountability in terms of transitional justice.

In this sense, the level of governmental expenditures aiming public policies and programmes concerning the protection of human rights is undoubtedly an indicator of how states deal in reality with the subject. Furthermore, the problem pertaining to these expenditures is not merely numerical (quantity of public expenditures), but also qualitative (particularly how public expenditures are allocated). In a country with the continental dimensions of Brazil, institutionally constructed under the foundations of federalism, public expenditures take place on three levels of governance: (1) central, the Union; (2) regional, the States (26 and the Federal District $^{14}$ ); and (3) local, the Municipalities (almost 6,000).

Furthermore, the abovementioned public policies and programmes are decentralized, with different ranges of autonomy distributed constitutionally among

\footnotetext{
${ }^{14}$ The Federal District in Brazil is the territory that hosts Brasilia, the capital city. Technically, the Brazilian Federal District is not a State, but it is positioned (within the hierarchy of Brazil's federalism) at the same level of the member States.
} 
the Union, the States, and the Municipalities. Additionally, and exactly because of decentralization, the protection of human rights is understood differently among the three spheres of governance (for example, differences regarding priorities).

Within the realm of the Union, for instance, and due to the fact that central government is controlled by the left-wing Partido dos Trabalhadores (Labour Party), the approach towards human rights has at all times been conceptualized, constructed, and performed inspired by the logic of confrontation against the conservative/traditional portions of Brazilian civil society, such as the media and the big landowners. The federal government (predominantly since the beginning of the term initiated in 2003 under the administration of Luiz Inácio Lula da Silva) finances social movements renowned for the invasion and destruction of great land properties, including productive farms.

The political decision to permanently subsidize radical social organizations, such as the Landless Peasants' Movement (MST) ${ }^{15}$ (ALSTON; MUELLER, 2003, p. 21), may be understood as a "moral obligation" (of ideological nature) from those sectors of the government historically, organically, and politically associated to these entities (including Lula da Silva himself). From 2003 to 2009, for example, the federal government has transferred $\mathrm{R} \$ 151,838,003.05$ (approximately $\mathfrak{E}$ $56,500,000.00)$ to NGOs connected to the MST. ${ }^{16}$ It must be emphasized that the public funding of these entities, during the administration of Lula da Silva, has been permanent at all periods of the aforementioned interval. In other words, the subvention in cause is part of the political decision from central government actors do finance NGOs associated to the MST, one of Brazil's most radical and violent social movements.

Under the sphere of the 27 provinces and the countless municipalities, expenditures regarding the protection of human rights will vary qualitatively and

\footnotetext{
15 "The MST originated in the South but shifted some of their efforts to the North. The MST knew that violence associated with land conflicts was harmful to the domestic and international reputation of politicians".

${ }^{16}$ Source:<http://contasabertas.uol.com.br/WebSite/Noticias/DetalheNoticias. aspx? Id $=2621>$.
} 
quantitatively, depending on decisions ranging from technical to moral inspirations, resulting from political to religious beliefs. One of the fundamental problems pertaining to the effective protection of human rights in Brazil is precisely the fact that the majority of the population (including all sectors from society) does not recognize human rights as an issue to be embraced as a priority of government.

On the one hand, the conservative portions of the Brazilian population (predominantly the upper and middle classes) understand human rights as theme from the left-wing of the political band; on the other hand, the lower classes, exactly the portion of the population requiring greater protection from the government, do not identify such protection as an outcome of their rights. In this case, the identification of the public policies and programmes connected to the protection of human rights is taken as an act of kindness from politicians, particularly on the poor regions of the country (in essence the northern territory).

Such distorted notion is a direct result of old practices that characterize the political mentality in Brazil, including the oligarchic roots placed deep inside society (José Sarney in Maranhão is an emblematic example) being nourished by the logic of exchange of favours (especially during periods of political campaigns): this endless cycle of dependency, fed by the ignorance and unawareness of the poor, together with the astute and artful techniques of the political elites, forms the basis of the recipe of governance in the country.

As initially affirmed, within the standpoint of transitional justice, accountability is essentially a matter pertaining to the formula equation past plus present. The "attempts to come to terms with a legacy" will vary enormously among those nations that experimented transition from times of authoritarian regimes to periods of democratic institutions. If South Africa faced within its transitional process the complex issue of racial discrimination, this was not the case of Brazil. If Eastern Europe dealt with the collapse of communism as a paradigm in its transitional period, such experience is definitely different from the historical shifts connected to transitional justice in Latin America (on the whole characterized by the transition from right-wing/anticommunist military governments to constitutional democracies). 
Amnesty was the Brazilian (official) mechanism of transitional justice adopted in the end of the military establishment. In 1979, the Brazilian national parliament approved a federal law (Law $\mathrm{n}^{\mathrm{o}} 6.683^{17}$ ) conceding amnesty to all individuals who committed political crimes (and crimes relating to these) within the period from 02 September 1961 to 15 August 1979. Even though still under military rule, the "last generals" had decided to build a bridge towards democracy. Such movement is indeed paradoxical.

On the one hand, the explanation to such phenomenon is fundamentally connected to personal and political convictions of some key military actors of the period (including Figueiredo and Geisel, the last two military presidents, both technocrats of liberal tradition); on the other hand, civil society in Brazil in the end of the 70's was more mobilized in comparison to the first decade of the military regime, in particular the urban middle class from important metropolitan centres, such as Rio de Janeiro and São Paulo.

A wide alliance (including leaderships from labour unions, students' organizations, the Catholic Church, the media, and other actors representative of an ample spectrum of sectors) was established inside and around the one and only oppositional political party of the country during that period (due to the bipartisan system imposed by the mentors of the regime): the Brazilian Democratic Movement Party (PMDB), a political reference to millions at that moment and nowadays nothing more than a container of corruption.

The constitutionality of the Lei da Anistia was recently submitted (April 2010) to judicial scrutiny inside the Supremo Tribunal Federal - STF (the supreme court of Brazil), with boisterous debates separating those in favour and those against the maintenance of the abovementioned law. By a $7-2$ difference (the court has eleven members, but two judges did not vote) the STF decided that Law no 6.683 does not violate the constitutional text. The court's pronouncement (in fact on the subject of the constitutionality of Article 1 of Law no ${ }^{-6.683}$ ) interpreted

\footnotetext{
${ }^{17}$ Source: <http://www3.dataprev.gov.br/sislex/paginas/42/1979/6683.htm>.
} 
the juridical extension of the 1979 amnesty benefits and effects (particularly in relation to the amplitude of the notion of "political crimes").

In practical terms, according to the court's interpretation, the punishment of "repression agents"18 (such as police officers and members of the Armed Forces) who committed crimes (including torture and other acts of violence) during the military period is just not possible. Even though sustained by a large majority, the decision of the Brazilian highest tribunal definitely did not settle the issue inside the country. In addition, it must be emphasized that the reaction to the sentence edited by the STF within the international community was not very friendly. David Tolbert, from the International Center for Transitional Justice - ICTJ, declared in April 2010:

No matter the decision taken yesterday, the search for truth and justice will continue. Regardless of whether it is pursued nationally or regionally, it is important to bring justice to victims of Brazil's military dictatorship and send a clear message regarding the importance of the rule of law. ${ }^{19}$

Under the emphatic headline "Brazil court upholds law that protects torturers",

Amnesty International has condemned the Brazilian Supreme Court's blocking of a reinterpretation of a 1979 Amnesty Law that protects members of the former military government from being put on trial for extrajudicial killings, torture and rape. The Supreme Federal Court judges on Thursday ruled seven to two to uphold the interpretation that crimes committed by members of the military regime were political acts and therefore covered by the amnesty. ${ }^{20}$

When Amnesty International decides to "condemn" the highest court of a sovereign nation, attacking one of its decisions, it remains patent, taking into account the "outside reaction" regarding the judicial pronouncement validating the

\footnotetext{
${ }^{18}$ Expression utilized by STF Judge Eros Grau in his vote.

${ }^{19}$ International Center for Transitional Justice-ICTJ Press Releases, 30 April 2010 (source: $<$ http://www.ictj.org/en/news/press/release/3692.html>).

${ }^{20}$ Amnesty International. News and Updates. 30 April 2010 (source: <http://www.amnesty. $\mathrm{org} / \mathrm{en} /$ news-and-updates/brazil-court-upholds-law-protects-torturers-2010-04-30>).
} 
Lei da Anistia in Brazil, that sectors from the international community (above all NGOs) not necessarily share the same positions and opinions coming from inside the country in cause, perhaps misinformed about the singularities of the judgement and about the historical and institutional limitations of Latin American countries upon the achievement of effective transitional justice. The abovementioned manifestation reveals the oversimplification of a problem that is far from being a straightforward issue. In Transitional Justice Genealogy, Teitel recognizes that local issues do in fact exercise profound impact upon the many possibilities regarding the implementation of transitional justice:

The deliberations over justice in transition are best understood when situated in the actual political realities and in the transitional political context, which included the features of the predecessor regime as well as political, juridical, and social contingencies. (TEITEL, 2003, p. 76).

Presiding the court in April 2010, Judge Cezar Peluso (unquestionably a genuine representative of the "inside reaction") declared: "só uma sociedade elevada é capaz de perdoar. Uma sociedade que quer lutar contra seus inimigos com as mesmas armas está condenada ao fracasso." ${ }^{21}$ On the one hand, Judge Peluso's words clearly associate transitional justice to forgiveness, a connection divergent (in conceptual terms) from the notion of reconciliation. Forgiveness ("a distinctive form of political apology") (TEITEL, 2003, p. 84) and reconciliation do not hold the same meaning, but perhaps to this particular judge and to other members of the Brazilian highest tribunal, the transition from military command to democracy in Brazil is a process that does indeed require forgiveness, not necessarily reconciliation. The issue is far from being a semantic controversy and reveals the perception of important public actors (judges from a nation's supreme court) upon transitional justice in Brazil.

On the other hand, it must be emphasized that within the particular case of Latin America, ideas such as forgiveness, mercy, compassion, grace, and cle-

21 "Only an elevated society is capable of forgiving. A society that wants to fight its enemies with the same weapons is condemned to failure" (source: <http://www1.folha.uol.com.br/ fsp/brasil/fc3004201003.htm>). 
mency (of evident religious background) are profoundly entrenched into cultural behaviours, political manners, and legal argumentations. There is no doubt about the fact that such approach to institutional issues tends to completely irrationalize deliberations and decisional processes. This was evident within the debates that took place inside the STF on the question about the validity of Law no -6.683 . Judge Marco Aurélio, for example, asserted that "amnesty is an all-embracing act of love, shaped upon the search of pacific conviviality among citizens."

A possible interpretation of STF's decision would be in the sense that (at least to seven judges) transitional justice in Brazil is an issue that has been legally settled in 1979. In fact, one of the arguments presented by former Judge Eros Grau in his vote was in the sense that the alteration of normative texts that concede amnesty is not a role of the STF. This is certainly a technical argument of legal nature, but the same judge also asserted that the Lei da Anistia was the result of a political accord, argument that confirms the idea upon which amnesty laws are definitely not a subject limited to legal matters. It is obvious that the topic is not simple and that a formal decision of a court is not sufficient to end and is not enough to shun the subject from debate. As a matter of fact, other Latin American nations edited amnesty laws in context of their transitions from military rule to democracy, including Chile (LEY DE AMNISTÍA, 1978), Argentina (LEY DE PACIFICACIÓN, 1983), and Uruguay (LEY DE LA CADUCIDAD DE LA PRETENSIÓN PUNITIVA DE ESTADO, 1986). Falta referências destas citações!

\subsection{The second element: justice}

What does justice mean in viewpoint of transitional justice? An evident way to face the question is to interpret the notion of justice as a component of a process of transition. The tautology here is certainly intentional with the purpose of establishing what justice is not in perspective of transitional justice. According to the definition proposed by the International Center for Transitional Justice - ICTJ,

Transitional justice is not a special form of justice but justice adapted to societies transforming themselves after a period of pervasive human rights abuse. In some cases, these 
transformations happen suddenly; in others, they may take place over many decades. ${ }^{22}$

The idea of "justice adapted", according to the abovementioned proposal, presupposes the existence of "societies transforming themselves" (societies in transition). Such idea, to say the least, will face towering hurdles when the subject is placed in terms of respect to rule-of-law values. In other words, although a category characterized by the trace of adaptation to transformation, transitional justice shall require both pre-existing and specific normative arrangements and instruments as a means to uphold its legal validity. In this case, the legislative branch must play a crucial role in the process of establishing (editing laws) these arrangements and instruments. As correctly observed by Byrnes and Renshaw, "all the organs of the state have a responsibility for observing and promoting human rights in their respective fields of responsibility" (BYRNES; RENSHAW, 2010, p. 511).

If, on the one hand, it is obvious that the legislative branch has the responsibility to generate laws (enactment of legislation), the fact is that in terms of functional categorization of its constitutional duties, national parliaments in Latin America are, in practical terms, mere appendices of the executive powers. In Brazil the phenomenon comes to a point where the national parliament faces virtual paralysis: from January 1999 to August 2004, almost $80 \%{ }^{23}$ of the federal laws edited by the national parliament were proposed by the Executive.

In other words, out of ten federal laws published in Brazil, only two were the result of parliamentary motivation. Many factors explain the aforesaid paralysis, including the customary promiscuous relationship between the Executive and the Legislative in Brazil on the subject of allocation of federal budget to municipalities (money to cultivate congressmen's local political interests), a priority to members of parliament. Passing laws has definitely been a secondary role of the Brazilian national parliament in the last decade, a phenomenon that undermines the credibility of the Legislative and corrodes the harmony among the powers of the state. The

${ }^{22}$ International Center for Transitional Justice - ICTJ. "What is Transitional Justice?" (source: $<$ http://ictj.org/en/tj/\#1>).

${ }^{23}$ Source: <http://bd.camara.gov.br/bd/bitstream/handle/bdcamara/1521/producao_legislativa_rodrigues.pdf?sequence $=1>$. 
problem is not limited to Brazil and many countries in Latin America (for example, Argentina and Paraguay) face the same institutional corrosion.

Under the formal structure of the Ministry of Justice, a rare case of legal mechanism on transitional justice in Brazil was the establishment of the Comissão de Anistia (Amnesty Commission) in 2001. The commission's main responsibility is to analyse compensation requests formulated by those individuals who were banned from the exercise of economic activities as a result of political motivation from September $1946^{24}$ to October $1988^{25}$ (including those individuals covered by the 1979 Lei da Anistia).

The commission has authorized, since its creation, financial compensations that currently exceed the extraordinary quantity of one and a half billion pounds (unevenly distributed amongst thirteen thousand individuals, approximately). ${ }^{26}$ According to official government prognosis, the Comissão de Anistia expects to receive 57 thousand compensation requests (including those already formulated). ${ }^{27}$ These requests are analysed by the members of the commission (total of 24) and the final decision regarding the acknowledgment or denial of compensation rests upon the Minister of Justice.

The compensations are granted on individual basis and the values are defined upon the periods of time on which victims have remained proscribed from professional activities in direct consequence of political motivation. The astonishing amount of money that has subsidized the abovementioned compensations in the last years has called the attention of the Tribunal de Contas da União - TCU (the Brazilian Court of Audit) and an internal investigation is at this time verifying the possible existence of irregular procedures and asymmetrical conclusions regarding the values defined for financial compensations.

\footnotetext{
${ }^{24} 18$ September 1946: data of promulgation of Brazil's fourth republican constitution.

${ }^{25}$ Source: <http://portal.mj.gov.br/data/Pages/MJABFF735EITEMID48C923D22C804143 AB475A47E582E1D8PTBRNN.htm>.

${ }^{26}$ Source: <http://www.estadao.com.br/estadaodehoje/20100814/not_imp594874,0.php>.

${ }^{27}$ Source: <http://portal.mj.gov.br/data/Pages/MJABFF735EITEMID48C923D22C804143 AB475A47E582E1D8PTBRNN.htm>.
} 
In accordance with the viewpoint of the Estado de São Paulo (one of the foremost newspapers in Brazil), a serious problem with respect to the decisions carried out by the Comissão de Anistia has connection to the issue concerning the "lack of criteria":

The lack of criteria inside the Comissão de Anistia produces flagrant absurds and injustices. It equalizes, through compensation, for example, the circumstances of Lamarca's death with those of Vladimir Herzog. It does not see difference between the violent repression upon whom, with arms, challenges the authority of the state (more than that of government), and the bestial repression that leads to torture and assassination of whom, unarmed, had surrendered to custody of the State. ${ }^{28}$

It is important to call attention to the fact that the Brazilian Comissão de Anistia functions on the basis of individual financial compensations remunerated with public funds. It holds absolutely no connection to the models of truth commissions installed in African countries, for example. In addition, its goals have nothing to do with reconciliation. One may criticize (and quite a few in Brazil do so) the open-handed approach of the Comissão de Anistia on the issue of the financial values for compensation, but many have argued that the commission has played a significant role in terms of assuring justice (financial) to thousands of victims.

In terms of implementing justice as a value of transitional justice, the chosen method of financial compensations is valid and legitimate, regardless of its conceptual and practical limitations; nevertheless, particularly in the Brazilian case, the mechanism adopted has created and nourished an environment of silence inspired by a tacit agreement upon both extremities of the confrontation that lasted from 1964 to 1985 .

On the one hand, current and former military actors remain rigorously and contentedly agreeable about the system of compensations for two basic reasons: first, the device adopted in the figure of an amnesty commission has "satisfied" the need of victims for justice (especially those who have received financial compen-

\footnotetext{
${ }^{28}$ Source: <http://www.estadao.com.br/estadaodehoje/20100814/not_imp594874,0.php>.
} 
sations) and very few people in Brazil today (from "both sides") would be willing to propose or defend the creation of truth commissions or similar instruments; second, it must be highlighted that $54 \%$ of the financial compensations (from 2005 to 2009) directly benefited former military officeholders. ${ }^{29}$ In other words, thousands of individuals (once again, from "both sides") profiting from their condition of anistiados políticos.

On the other hand, the traditional victims of the military period - the leftists - have been in power for the last eight years, and many of these individuals have received financial compensations from the Comissão de Anistia. If the price to be paid is silence regarding the past abuses, this seems not to be a problem in the name of stable governance (meaning no confrontation with the military, today or in the future).

The Brazilian approach to justice in context of transitional justice can be represented by the following equation: amnesty plus compensation. Amnesty in perspective of the 1979 Lei da Anistia and compensation in terms of the prerogatives resulting from the legislation that created the Comissão de Anistia. Taking into consideration the recent decision of the STF validating and confirming the constitutionality of Law no $\mathbf{6} .683$, it is reasonable to affirm that Brazil has decided to discard trials for the crimes perpetrated by its former military regime. It is unlikely that such decision, with all of its political implications, shall be modified in the near future.

If, on the one hand, the creation of a truth commission in Brazil is improbable, on the other hand the punishment of those individuals responsible for crimes committed during the dictatorial period turned out to be virtually impossible. The Brazilian experience of transitional justice, to say the minimum, has been a confusing compilation of fragmented and disconnected historical events and state initiatives: 1979, 1985, 1988, 2001, 2010. There is no pattern within the timeframe between the publication of the Lei da Anistia and the decision of the STF. What has

\footnotetext{
${ }^{29}$ Source: <http://noticias.r7.com/brasil/noticias/anistiados-politicos-ja-receberam-maisde-r-3-bilhoes-em-indenizacoes-desde-2003-20100821.html>.
} 
remained clear during the last three decades in Brazilian history is the total absence of continuity regarding the conception and creation of mechanisms related to transitional justice.

It is also clear that the issues regarding domestic jurisdiction and state sovereignty still represent a barrier to effective transitional justice. At the same time, the autonomy of the three branches of power is factual (to a lesser or to a higher degree) and internal decisions, under periods of institutional normality, must me taken as legitimate (but not necessarily rational and fair). This intricate relationship between internal affairs and international justice is a theme crucial to international law. As correctly underscored by Robertson,

It has been the great achievement of international law, by the dawn of the twenty-first century, to lift the veil of sovereign statehood far enough to make individuals responsible for the crimes against humanity committed by the states they formally commanded, while at the same time developing a rule that those states have a continuing duty to prosecute and punish them, failing which another state or the international community may bring them to justice (ROBERTSON, 2006, p. 283).

\subsection{The third element: reconciliation}

As affirmed by Avruch and Vejarano, "reconciliation, so crucial to peace and stability" (AVRUCH; VEJARANO, 2001, p. 41), is the element of transitional justice that aims pacification inside societies in transition. The idea demands the conference of perpetrators and victims. According to the aforesaid authors (alluding to Joseph Montville), "the process of reconciliation can be broken down into the formula of acknowledgment and contrition from the perpetrators, and forgiveness from the victims" (AVRUCH; VEJARANO, 2001, p. 41). As a result, reconciliation will necessarily occur in perspective of a binary relationship, with perpetrators and victims trying to construct the culture of "sustainable peace":

Political reconciliation involves taking the first steps to achieve the higher goal of sustainable peace. In the words of a Dinka elder, reflecting on the Sudanese conflict, 
'reconciliation begins by agreeing to sit under the same tree with your enemy, to find a way of addressing the causes of the conflict.' This is a process that prioritises dialogue and understanding (VILLA-VICENCIO, 2004, p. 78).

Different countries have utilized diverse mechanisms on the subject of reconciliation. The creation of truth commissions, for example, was a device chosen by many nations in order to attempt reconciliation in perspective of transitional justice. As highlighted by Avruch and Vejarano, "since 1973, more than 20 "truth commissions" have been established around the world, with the majority (15) created between 1974 - 1994. Some were created by international organizations like the United Nations (UN), a few by nongovernmental organizations (NGOs), and the majority by the national governments of the countries in question" (VILLA-VICENCIO, 2004, p. 37)

In Latin America, governmentally subsidized commissions include Argentina (1983 - 1984), Bolivia (1982 - 1984), Chile (1990 - 1991), and Uruguay (1985). In Brazil, as well evoked by the United States Institute of Peace - USIP, a commission of inquiry with particular characteristics, functioning under extraordinary circumstances, was organized as an unofficial project from 1979 to 1982:

After civilian rule was restored in 1985, a research team sponsored by Cardinal Paulo Evaristo Arns, archbishop of São Paulo, and supported by the World Council of Churches, conducted a confidential research project to investigate allegations of torture and other human rights abuses committed during the prior two decades. The researchers used military trial transcripts between 1964 and 1979 as a basis for their findings. These transcripts were never intended to be read by the public at large. Ironically, however, the 1979 amnesty law provided activists with a pretext to access the military files. Lawyers were permitted to access to the archives to prepare amnesty petitions on behalf of their clients and could check out the files for 24 hours. The researchers began to systematically copy page after page of the borrowed files until the entire records in the holdings of the Military Supreme Court were duplicated. ${ }^{30}$

\footnotetext{
${ }^{30}$ United States Institute of Peace - USIP Commission of Inquiry: Brazil.
} 
The Brazilian project was only possible due to the fact that sections from the Catholic Church decided to put into practice the abovementioned research over the trial transcripts. In other words, it was not a project organized or financed by the government. In fact, it is absolutely fair to assert that without the interference of important sectors of the Catholic Church (principally from the upper hierarchy) in political affairs during the military regime, dictatorship in Brazil would probably last years more.

The concrete action of the Catholic Church, including the physical protection and sheltering of hundreds of dissidents, was decisive to challenge and destabilize the military establishment (particularly during the last years of the regime). This is an important piece of information in the sense that it indicates a singular characteristic of all democratic governments installed in Brazil since 1985: the total incapacity to deal politically with the subject concerning the creation of formal reconciliation mechanisms. Even the current government, integrated by many individuals tortured during the military period (President Dilma Rousseff herself a victim) has not managed to appraise this and other issues on transitional justice.

In general terms, the creation of a truth commission in Brazil sponsored by the government would encounter brutal resistance inside the military segment (including officials that even though formally retired still maintain fractions of power within the Armed Forces). Furthermore, it must be emphasized that differently from the transitional justice model implemented in South Africa, for example, where the apartheid regime produced impact upon millions of people, reconciliation (here understood as a procedure inherent to transitional justice) in Brazil is definitely not a subject of public concern.

A possible process of reconciliation in the country, taking the form of a truth commission, would probably be limited to individual (interpersonal) reconciliation, not meaning that such type of reconciliation is unimportant. In fact, "interpersonal reconciliation is perhaps the most profound form of reconciliation. Where successful, it can have an emotionally or spiritually healing effect on both the victim and the victimiser. On the whole, though, it is relatively 
rare." ${ }^{31}$ The possibility of communal reconciliation in Brazil, particularly among opposing political groups, is unlikely.

First, taking into account the temporal gap separating past and present (almost three decades), it is doubtful that the remaining political actors of the 1964 - 1985 period still hold any motivation to carry on formal and exhausting procedures inherent to the reconciliation process. Second, in paradoxical terms, the dimension of the aforesaid gap was not sufficient to build an environment of reconciliation to unite the opposing groups in order to settle down issues from the past. Radicalization from both extremities (independently of its degrees) is still a factor that truly diminishes the possibility of reconciliation.

In comparative historical terms, however, the dictatorial period in Brazil from 1964 to 1985 holds a completely diverse dynamics from that of other authoritarian regimes in Latin America and other regions of the world, including the level of radicalization between opposing groups, the intensity of repression, and the number of victims. As confirmed by O'Donnell, military government in Brazil "was only moderately repressive" and "repression was less massive, continuous, and systematic than in the other cases" (O'DONNELL, 1995, p. 435).

Inside Argentina, for example, a smaller country in territorial and population terms, the magnitude of repression and the number of victims during the military years was much higher in comparison to the Brazilian case. In the words of Kritz, in Argentina "the military unleashed a vicious campaign that came to be known as the "dirty war" for its brutality and continued it long after the elimination of any armed threat from the left (...)." (KRITZ, 1995, p. 323). At the same time, it is important to recall that inside Latin America, "Argentina remains the only nation that has indicted and prosecuted military officers for their role in repression." (PION-BERLIN, 1995, p. 82).

\footnotetext{
${ }^{31}$ Source: <http://www.ipu.org/PDF/publications/reconciliation_en.pdf>.
} 


\section{Conclusion}

Diverse historical experiences regarding societies in transition imply that a functional notion of transitional justice (including different approaches concerning accountability, justice, and reconciliation) must take into account specific local realities and domestic contingencies, political, juridical, and cultural. This is perhaps the fundamental characteristic of the idea of transitional justice: its validity rests upon the broad scope of its purposes. Furthermore, transitional justice may be understood as a rational political and juridical reference to governments and societies that experienced the dramatic conversion from dictatorial systems to democratic regimes, the typical case of many Latin American countries during the $20^{\text {th }}$ century.

Rationality, in this case, as an orientation to encourage and promote actions and practices aiming accountability, justice, and reconciliation. Independently of how different societies have decided to face and manage transitional justice, it is fair to affirm that those countries that came across the issue gained in terms of democratic governance. Moreover, when the three elements of transitional justice are comprehended and recognized as values inherent to the effective protection of human rights, the same democratic governance will depart from the sphere of abstract paradigms to the realm of concrete public policies.

Within societies in transition, how much does a national government spend a year with programmes concerning the protection of human rights? How are these programmes thought and put into practice? What are the priorities? Who are the individuals to be protected? The answers to these questions represent, in practical terms, the domestic behaviour of states in perspective of human rights, and the response of authorities to these issues in countries facing transitional justice is crucial to explain the triumph (or failure) of governance. Byrnes and Renshaw emphasize the role of the Executive in the following terms:

"The role of the executive in protecting human rights is also critical. The executive should have procedures in place to ensure that it takes into account both its positive and negative obligations in relation to human rights when deciding on its policy priorities and in assessing the appropriateness of its approach to implementing them." (BYRNES; RENSHAW, 2010, p. 513). 
In a country like Brazil, with all of its cultural intricacy, the official political discourse regarding human rights has been standardized after the edition of the 1988 Constitution, a normative kaleidoscope of fundamental rights produced in context of the historical shift from authoritarian rule to democratic regime. Concrete governmental action with reference to the protection of human rights in Brazil, nonetheless, is still far from the primary intents of the drafters of the new constitutional text and miles away from the implementation of effective and transparent public policies on the protection of human rights.

In addition, the same discourse on the subject of human rights is abundantly fed by components of political demagoguery as a means to broadcast artificial messages of due respect to basic human values. The construction of "sustainable peace" is certainly possible in emerging democracies, but concrete action from government on human rights must be enduring and based on domestic contingencies and local realities (including regional diversity). It is absolutely impossible, for example, to build peace inside a nation in transition when the carceral system of the country in cause has been transformed in a horrifying dungeon, a true school of crime.

Finally, it is a myth, to say the least, that a country like Brazil is a peaceful nation. An old fable sustained by historical misinformation, cultural misunderstanding, and political delusion. The dramatic issue regarding the violent and corrupt Brazilian carceral apparatus is just a single particle inside a universe of problems concerning the continuous violation of human rights in Latin America's largest nation.

\section{Justiça transicional no Brasil: da ditadura militar para uma nova ordem constitucional}

\section{Resumo}

A implemantação da justiça transicional em países latino-americanos que experimentaram o regime militar ainda é um desafio para muitas nações da região. Devido a diferentes razões políticas, culturais e históricas, distintos modelos 
de justiça transicional têm sido utilizados na América Latina. O presente artigo pretende analisar algumas questões e problemas relacionados com a experiência de justiça transicional do Brasil, um país controlado por forças militares de 1964 a 1985. O artigo inclui uma breve história das singularidades políticas do Brasil nos últimos 30 anos e enfatiza o estudo da noção de justiça transicional na perspectiva de três elementos: justiça, responsabilidade e reconciliação. Um dos principais argumentos do artigo se assenta na ideia de que a implementação de padrões predeterminados de regimes de justiça transicional é impossível, exatamente porque responsabilidade, justiça e reconciliação possuem e mantêm diversos significados em diferentes países com experiências históricas, políticas e culturais distintas. $\mathrm{O}$ processo sobre o qual estes elementos se estruturam para racionalmente realizar a justiça transicional, sem dúvida, representa uma questão a ser considerada pelos governos e sociedades civis nas novas democracias como o Brasil. Finalmente, o artigo sustenta a seguinte proposição: uma noção funcional de justiça transicional (incluindo abordagens diferentes a respeito de responsabilidade, justiça e reconciliação) deve levar em consideração as realidades particulares locais e contingências internas de natureza política, jurídica e cultural.

Palavras-chave: Justiça transicional. Responsabilidade. Justiça. Reconciliação. Regimes militares. Novas democracias na América Latina. Direitos humanos.

\section{Bibliography}

ALSTON, Lee J.; MUELLER, Bernardo. Property rights, violence and the state. Working Paper. Brasília, n. 293, p. 21, may 2003. Available at: <http://vsites.unb.br/ face/eco/cpe/TD/293May03BMueller.pdf >. Access on: dec. 2010

AVRUCH, Kevin; VEJARANO, Beatriz. Truth and reconciliation commissions: a review essay and annotated bibliography. In: Social Justice: anthropology, peace and human rights. Arlington, v. 2, n. 1-2, p. 47-108, 2001. Available at: <http:// www.trinstitute.org/ojpcr/4_2recon.pdf >. Access on: nov. 2010

BYRNES, Andrew; RENSHAW, Catherine. Within the state. In:. MOECKLI, Daniel; SHAH, Sangeeta; SIVAKUMARA, Sandesh (Ed.). International human rights Law. Oxford: Oxford University, 2010, p. 506. 
COIMBRA, Cecília Maria Bouças. Tortura no Brasil como herança cultural dos períodos autoritários. R. CEJ. Brasília, n. 14, p. 5-13, maio/ago. 2001. Available at: $<$ http://www.dhnet.org.br/denunciar/tortura/a_pdf/cecilia_coimbra_tortura_br_ cultural.pdf $>$. Access on: dec. 2010

BRAZIL. Constitution (1988). Available at: <http://www.v-brazil.com/government/ laws/constitution.html>. Access on: nov. 2010

ESTADOS UNIDOS DA AMÉRICA. The Universal Declaration of Human Rights. Available at: <http://www.un.org/en/documents/udhr/index.shtml>. Access on:

KRITZ, Neil. (Ed.). Transitional justice: how emerging democracies reckon with former regimes. Washington, D.C.: United States Institute of Peace, 1995. v. 2.

LEY DE AMNISTÍA, 1978, Argentina.

LEY DE PACIFICACIÓN, 1983, Argentina.

LEY DE LA CADUCIDAD DE LA PRETENSIÓN PUNITIVA DE ESTADO, 1986, Uruguay.

MÉNDEZ, Juan E. In defense of transitional justice. In: McADAMS, James (Ed.). Transitional justice and the rule of law in new democracies. Notre Dame: University of Notre Dame, 1997.

O’DONNELL, Guillermo. Brazil (Country Studies). In: KRITZ, Neil (Ed.). Transitional justice: how emerging democracies reckon with former regimes. Washington, D.C.: United States Institute of Peace, 1995. v. 2, p. 435.

PION-BERLIN, David. To prosecute or to pardon: human rights decisions in the Latin American Southern Cone (General Considerations). In: KRITZ, Neil (Ed.). Transitional justice: how emerging democracies reckon with former regimes.. Washington, D.C.: United States Institute of Peace, 1995. v. 1, P. 82.

POWER, Timothy J. The masses and the critical mass: a strategic choice model of the transition to democracy in Brazil. Paper, Texas, n. 87-11, p. 3-4, april 1987. Available at: <http://lanic.utexas.edu/project/etext/llilas/tpla/8711.pdf >. Access on: nov. 2010.

RAWLS, John. A theory of justice. Cambridge, Massachusetts: Harvard University, 2003. 
ROBERTSON, Geoffrey. Crimes against humanity: the struggle for global justice. London: Penguin Group, 2006.

RODLEY, Nigel. Integrity of the person. In: MOECKLI, Daniel; SHAH, Sangeeta; SIVAKUMARAN, Sandesh. International human rights law Oxford: Oxford University, 2010. v. 3, cap. 10, p. 210.

SANDS, Philippe. Principles of international environmental law. Cambridge: Cambridge University, 2003.

SANTOS, Maria Helena de Castro. The Brazilian military in post-democratic transition. En publicacion: Revista Fuerzas Armadas y Sociedad. Santiago, año 18, n. 3-4. jul./dic., 2004.

SKIDMORE, Thomas. Brasil: de Castelo a Tancredo. Rio de Janeiro: Paz e Terra, 1988.

TEITEL, Ruti. Transitional justice. New York: Oxford University, 1999.

TEITEL, Ruti. Transitional justice genealogy. Harvard Human Rights Journal. Cambridge, v. 16, p. 69-94, primavera 2003.

VILLA-VICENCIO, Charles; DOXTADER, Erik (Ed.). Pieces of the Puzzle: keywords on reconciliation and transitional justice. Cape Town: Institute for Justice and Reconciliation, 2004. Available at: <http://www.africanminds.co.za/books/ Pieces\%20of\%20the\%20Puzzle\%20-\%20Keywords\%20on\%20Reconcilation\%20 and\%20Transitional\%20Justice.pdf >). Access on: out. 2010. 


\section{Para publicar na revista Universitas}

Relações Internacionais, entre no endereço eletrônico www.publicacoesacademicas.uniceub.br. Observe as normas de publicação, facilitando e agilizando o trabalho de edição. 